\title{
Factors Affecting the Decision of Selecting Banking to Save Money of Individual Customers - Experimental in Da Nang City
}

\author{
Le Anh Tuan ${ }^{1,2, *}$, Mai Thi Quynh Nhu ${ }^{1,2}$, Nguyen Le Nhan ${ }^{1,2}$ \\ ${ }^{1}$ Faculty of Accounting, Duy Tan University, Da Nang, 550000, Vietnam \\ ${ }_{2}^{2}$ Institute of Research and Development, Duy Tan University, Da Nang, 550000, Vietnam
}

\begin{tabular}{l} 
A R T I C L E I N F O \\
\hline Article history: \\
Received: 08 March, 2021 \\
Accepted: 09 May, 2021 \\
Online: 27 June, 2021 \\
\hline Keywords: \\
Savings deposits \\
Individual customers \\
Da Nang \\
\hline
\end{tabular}

\begin{abstract}
A B S T R A C T
The purpose of this study is to evaluate the factors affecting the decisions of factors affecting the decision of individual customers to choose a savings bank at commercial banks in Da Nang city. . Through the use of appropriate research methods, the authors have found that there are 5 factors with 5 groups of factors that greatly affect the decision of individual customers to choose a savings bank. Service quality, safety, stakeholder influence, financial benefit, convenience. Through this result, it will help opinions, orientations and solutions to improve individual customers' decisions on choosing a savings bank at joint stock commercial banks in Da Nang city.
\end{abstract}

\section{Introduction}

In today's competitive open economy, commercial banks always find ways to use many attractive and novel savings products to attract customers to their banks. On the part of customers using the service, they are also interested in factors related to the benefits of saving money at banks. This is also something that bank managers are interested in understanding, so identifying the factors that affect individual customers' choice of banks when saving money is a necessary job to help. Banks promote their strengths, enhance their image in the eyes of customers to attract more idle money from the population, contributing to improving business efficiency.

In 2018-2019, the macroeconomic situation and Da Nang continue to face many challenges. However, with the efforts of the whole political system, Da Nang has achieved many successes in the realization of local socio-economic development goals; in which, the banking sector has made an important contribution to the socio-economic development of Da Nang. Through general assessment of the banking performance of the city. In Da Nang in 2018-19, it is remarkable that the operations of the banking system in the area continue to grow compared to the previous years. By the end of 2018, the total mobilized capital in the province was about VND 125,994 billion, up 9.92\% compared to the end of 2017, the highest growth rate in recent years (up 25.84\%). In

"Corresponding Author: Le Anh Tuan, Email: latuan0507@gmail.com.

www.astesj.com

https://dx.doi.org/10.25046/aj060345 which, 36/57 credit institutions have increased mobilized capital compared to the end of 2017 , contributing greatly to the recovery and development of the business community in the city.

Each bank has its own capital mobilization policy, depending on the needs and purposes of its business. To have a large capital source requires commercial banks to have appropriate mobilization policies to attract the necessary amount of capital in the economy to serve their business and development. Although there is a high credit growth rate compared to the whole country (about 14\%), the bad debt rate is low at $1.62 \%$. At the same time, at the end of 2018, banks increased deposit and lending rates to stimulate demand, attract capital, and the impact of exchange rates and liquidity pressure. Techcombank raised interest rates for 1236 -month term from $6.4 \%$ a year to $6.8 \%$. VIB applies $7.3 \%$ for the 24-month term. ACB also applies a new interest rate schedule for deposits with terms over 18 months, ranging from $7-7.2 \%$ a year, 0.1-0.3\% higher than May.

\section{Background Study}

Up to now, there have been many practical studies on the adoption and use of e-banking services, including studies on the factors influencing the decision to use services. Typical electronic banking services. In [1], the author presented that intention is considered to include motivational factors that influence the behavior of each individual. These factors indicate the willingness or effort that each individual will put in the behavior. The above 
definition explains behavior that is influenced by a person's confidence in his or her ability to perform the behavior. Therefore, behavior is affected by controlling cognitive and intent behaviors as well as attitudes, subjective criteria and perceptions of behavior controlling indirectly through intentions. In [2] the author expand the application of two Mobile banking service by adding the element of trust ("Feeling of trust") and 2 source factors ("Selfgrasping ability" and "financial cost perception") into the model, and focus on the position of these factors in the existing structure of the TAM model. . In [3], the author define that behavioral intent is the ability of the consumer to use an innovation. With higher behavioral intentions, consumers will be more likely to use a new technology. There are a number of premises that can affect an individual's behavioral intentions. Applying the UTAUT model to study the behavior of $3 \mathrm{G}$ mobile telecommunications users in [4]. The author used the UTAUT model to conduct research surveys. The research results show that the factors that influence the "behavioral intent" include: "expectation of the effect", "social influence" and "favorable conditions", while the factor "expectations" in terms of effort" has no effect. In addition, three unrecognized relationships were discovered during the SEM analysis, modifying the UTAUT model for 3G telecommunications services. The biggest difference between this study and UTAUT theory is the issue of time of study and the significance of the determinant by external variables. Studying the factors affecting the intention to use online shopping services using the UTAUT model in [5]. The study identified 6 factors affecting the intention to use e-shopping services, including: (1) Expectation about price, (2) Perceived convenience, (3) Perception ease of use (4) Feel the pleasure, (5) Social influence, (6) Feel the risk of use. In addition, the model will also consider the influence on the intended use of three demographic variables: gender, income, and age. Inheriting the point of view of the above researchers, in [6], the author describes customers' savings deposit behavior expressed in choosing a bank and choosing a deposit period. Research on factors affecting the acceptability of Mobile Banking of individual customers applying the UTAUT model in [4]. Using the Unified Theory of Technology Acceptance and Use (UTAUT) to investigate the effects on people through Mobile banking, this study concludes that individuals' intentions on mobile services Banking is significantly affected by the following factors: (1) social influence, (2) perceived financial costs, (3) performance expectation, and (4) perceived trust in order of influence. Behaviors are significantly influenced by personal intentions and favorable conditions. This study found that gender controls the effect of performance expectations and financial cost perceptions on behavioral intent, age of adjustment, effects of favorable conditions, and perceived self-grasping. to real acceptance behavior.

Data were collected from 165 questionnaires and used regression to analyze relationships in [7]. The results have shown that all factors, except the "perceived cost" factor, have a significant impact on behavioral intent in using Mobile Banking. "Feeling useful" is the most influential factor in explaining the user's intent to accept. For users, "feel the ease of use" is the most important factor, while "feel efficient" significantly affects the intention of accepting the service. The results from these analyzes help banking organizations to have a suitable strategy for Mobile banking to expand their acceptability of this service. Background theory related to rational action theory (TRA) developed in [8] and in [9] shows the inclusion and coordination of the components of attitudes in a structure. which are designed to better predict and explain consumer behavior in society based on two basic concepts: (i) consumer attitudes toward behavior and (ii) subjective standards of consumers. In addition, the intended behavioral theory (TPB) was developed in [9] by adding a cognitive element of behavior control to the TRA model. According to TPB, human behavior is guided by 3 factors: behavioral beliefs, normative beliefs and controlling beliefs. Thus, beliefs about behavior create an attitude of like or dislike about behavior; normative beliefs create subjective social or normative stress and controlling beliefs increase cognitive behavioral control.

Thus, most studies using TAM model are conducted based on the adoption and use of information / technology systems. In studies, the TAM model was found to be valuable in predicting the adoption of variables in the user system. However, in many areas, as mentioned earlier, the original TAM model does not fully explain behavioral intent towards technology adoption and adoption, and there is a need for research to add factors to improve predictability for this model. Up to now, there have been many studies on individual customer banking choices conducted in many different countries around the world, with many different survey subjects. This is a rich source of documents, the basis of orientation to conduct research on factors affecting the choice of banks of individual customers at joint stock commercial banks. Not to mention the research on the earliest bank selection criteria in the US, in [10], the author showed that the recommendation of friends is the most important factor, followed by reputation, reputation. of the bank and large loan capital. In the American university student article, in [11], the author presented that convenience is still the main reason most students choose their bank. In addition, family tradition and loyalty to the bank are also important factors for college students. In [12], the following factors are identified as the decisive attributes affecting the choice of banks: service fee collection policy, reputation, loan interest rate, disbursement time and friendly bank staff. In [13], it is reported that economic factors such as monthly costs and deposit interest play a decisive role in student's choice of bank. In [13], The author found fast and efficient service delivery, friendly, enthusiastic staff and a bank reputation are important factors in choosing select the student's bank. In [14], the author showed that the key factors influencing customer choice in Greece include: convenience, reputation of a bank, quality of products / services., interest rates and fees, staff communication skills and qualifications, facilities, the environment of the points of sale, and satisfaction with after-sales service and services.

There have been many empirical studies at home and abroad on the factors affecting the decisions of individual customers to deposit money at banks in [15]-[19].The important factors affecting the deposit behavior of customers are financial interests, brand awareness, influence of relatives, fast and safe, marketing, service style of employees, delivery Convenient translation and safe feeling. In [20], the banking selection criteria of Business Administration students in Delhi, India concluded that convenience is an important determinant, Includes: parking, free delivery on demand, phonebanking, free home money transfer service because customers want to save time. In [21], the author conducted in Malaysia found three factors that most influence a 410 
student's banking choice: sense of security, ATM service, and financial benefits. In [16], the author conducted a similar study to determine the factors influencing the choice of commercial banking of university students in South Africa. The study was based on a sample of 186 students from Fort Hare University (Alice campus). The researchers found that the important factors that determine a college student's choice of banking (ranked in diminishing importance) are: service, convenient location, attractiveness, gender referrals of others, marketing activities and prices. In [22], the author studied the factors affecting customer satisfaction in the banking industry in Pakistan to find the relationship between service quality, satisfaction and loyalty. customers. The research results show that $54 \%$ change in customer loyalty is due to service quality and customer satisfaction. The study concludes that, service quality affects customer satisfaction and customer satisfaction affects customer loyalty. In today's competitive marketplace, banks can gain a competitive edge by providing quality services that meet the needs of their customers.

For studies in this area in Vietnam, there has been a study on factors affecting the choice of banks of individual customers in [23] surveyed above. 350 individual customers in Da Lat city concluded that brand awareness has the strongest impact on the trend of choosing a bank, followed by factors: Convenience in terms of location, troubleshooting, photos enjoyment of a loved one, appearance and attitude toward marketing. Meanwhile, in [24], the author surveyed 200 customers using banking products and services showed that there is a positive relationship between customer satisfaction and reliability factors. feedback, accessibility, service capacity and quality of products and services. No correlation has been found between information and customer satisfaction. Based on the research results, a few recommendations have been proposed to improve the satisfaction of individual customers with Vietinbank East Hanoi branch in particular and other commercial banks in general. In [25], the author presented on the factors affecting the choice of savings banks of individual customers in Ho Chi Minh City, researched and surveyed over 500 customers. In [25], the author focused on testing the factors of service quality affecting satisfaction and loyalty. In which, testing a number of impacts that regulate the relationship of satisfaction loyalty of customers for banking services in Hau Giang. Based on a survey sample from 333 customers, Cronbach's Alpha coefficients, exploratory factor analysis, confirmatory factor analysis and structural equation model were used for analysis. The results show that empathy and price are the factors that strongly impact on customer satisfaction. In [26], the author studied the factors affecting the satisfaction of customers with the savings deposit service at Agribank Binh Minh, Vinh Long. Research results show that, 4 main factors affecting customer satisfaction including responsiveness, facilities, service capacity and peace of mind. The relationship between the service quality and the satisfaction of customers participating in the transaction is very important to the operation of the retail bank.

The results of this study have identified 8 groups of factors that affect individual customers' banking choices, including: financial benefits, sense of security, referral, troubleshooting, service. Bank, brand, staff, convenience. At the same time also evaluate their importance. This is the guiding basis for commercial banks to take action measures that focus on key factors to influence customers' choice of banks and thereby attract more. customers using their www.astesj.com bank's retail products and services. Based on the research results, the author gives some suggestions to help banks maintain existing customers and attract new customers. From there, the leaders of banks can refer to make appropriate policies to increase the competitiveness of banks in the retail market. In [27], the author showed on the factors affecting the decision of individual customers to deposit savings - Research at Joint Stock Commercial Bank for Industry and Trade of Vietnam, Lam Dong province, based on into data collected from 184 observations processed by SPSS tool, with Cronbachs Alpha scale reliability testing techniques, factor analysis (EFA), correlation analysis and multiple regression analysis . Research results have identified 5 factors that directly affect individual customers' decisions to save money, including: brand awareness, influence of relatives, financial benefits, fast, safe and marketing. Based on the research results, governance implications have been proposed to better meet customer needs and expand markets to attract new customers. In [23], the author studied the factors affecting individual customer satisfaction with deposit products at Lien Viet Post Joint Stock Commercial Bank - Soc Trang Branch. Research results have found out 5 factors affecting the satisfaction of customers who save money at this bank are: Reliability; Tangible Media; guarantee; sympathy; Transaction office network. In which, tangible means, assurance, sympathy, and transaction office network are the factors that strongly affect the satisfaction of savings customers. As can be seen, the factor that is considered important by the customer when choosing banks varies from country to country and cultures due to differences in economic, cultural and banking systems.

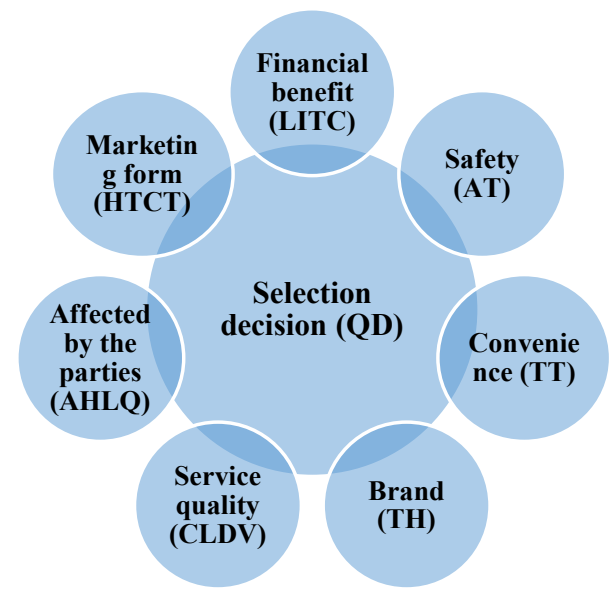

Figure 1: Proposed research model (Source: Author compiled, 2020)

\section{Research Methods}

After consulting domestic and foreign research models, survey experts with the list and content as outlined in the discussion paper. The authors have formed a preliminary scale of factors affecting the decision of individual customers to choose a savings bank at commercial banks in Da Nang city to be used when surveying ideas. the experts. After synthesizing the answers of experts about the factors in the preliminary scale. The results of qualitative expert survey showed a high rate of agreement (over $80 \%$ ) on 7 groups of factors and experts did not add any new groups of factors. After collecting information from the most knowledgeable and experienced staff about deposit services and customers who are conducting transactions at joint stock commercial banks who 
have sent savings and intend to save money in the near future. With the model study on an overview of the research situation related to the factors that influence the decision to choose a bank to deposit a savings, we expect an analytical framework with 5 common factors affecting decide to choose a bank to save individual customers as follows:

Based on the research objectives, the survey and research model of the proposed factors influencing the decision to buy Korean facial care products by female university students in Da Nang city, based on the background theory presented above, the research hypotheses are determined as follows:

\section{Hypothesis H1: Financial benefits (LITC) and decision to choose a savings bank of individual customers have positive relationship.}

Financial benefits are assessed through two criteria: High saving interest rate and reasonable service fee. Savings deposit interest rate is an indispensable question of customers when looking for information about savings deposit service at a certain bank. Interest is the rate of interest a customer receives in addition to the principal, after a certain period of time at the bank. The bank uses a currency that customers commit to deposit with a fixed term to do business and seek profits, and pay interest on that deposit currency. Interest can be paid at the beginning of the term, paid periodically, or at the end of the term. In the banking sector in Vietnam, competition by savings interest rates is a traditional competitive measure to attract deposits. Interest rate is also the basic factor when customers choose a bank to save money.

Service fee is the cost that a customer has to pay to use banking products and services. When an individual customer comes to the bank not only to save money but also transact in many other areas such as proof of finance, transfer ... - maybe equal to the amount of money that has been saved. If products and services do not have big differences in characteristics and benefits, customers tend to choose products and services with lower costs. Therefore, service costs may also be a concern for customers when choosing a bank to save money.

Hypothesis H2: The safety (AT) and decision of individual customers to choose a savings bank have a positive relationship.

Transactions at banks are often sensitive because they are directly related to customers' financial resources, so a sense of security is a factor worth considering. In [15], the author pointed out that a sense of security reflects a desire of banking users to be stable and secure when making financial transactions. This means a sense of security that includes both security at banks and bank financial stability. Therefore, there are three criteria: Secure customer information, Strong banking financial foundation, Security conditions of transaction points are used to assess the sense of security of customers about the performing bank.

\section{Hypothesis H3: Convenience (TT) and the individual customer's decision to choose a savings bank has a positive relationship.}

Another characteristic of individual customers when conducting financial transactions is that they prioritize services that are provided quickly and can be done anywhere, at any time. This convenience is measured through 7 criteria: the large network of transaction points, the location of convenient transaction points, having a transaction point near home / workplace, suitable bank transaction time, there is ample parking, e-banking available and free home deposit service. The network and location of transaction points provide customers with convenient mobility. Customers can deposit money in one city and withdraw money, transfer money ... in another city. In other words, individuals can perform transactions with the bank at any point in the system thanks to the development of information technology in the banking sector without spending much time and effort on going. again. Often times, the transaction points near home and work are arguably the most attractive. In addition, the spacious parking not only brings a sense of safety but also helps customers more convenient when dealing directly with the bank. Another factor that is considered is the bank's working time in accordance with the individual transaction schedule. Clients with flexible hours of work may not appreciate the fact that banks are open for transactions outside of office hours. On the contrary, for civil servants and office workers - who are often forced by strict working hours, the bank's acceptance of overtime will help them a lot in transactions.

Nowadays, when science and technology are developing rapidly, electronic transactions are expected to be one of the factors attracting customers for convenience. Individuals can perform transactions with the bank whether at home or on the street, with only one device with network connection such as laptop, desk phone, mobile phone ... Instead of having to directly go to bank transactions. Customers, individual customers can transfer, pay electricity and water bills, pay credit card bills or even save money, pay off loans, manage accounts at home, work with just few simple steps. Some other utilities such as free home deposit service should also be deployed for maximum convenience for customers.

Hypothesis H4: Brand (TH) and individual customers' decision to choose a savings bank has a positive relationship.

Combining a number of studies and factors Brand awareness is evaluated through the following observed variables: Recognition of the bank's brand name, logo, image, signature music, Community programs, activities Big sponsorship that the bank participates in and Promotions. In [28], the author showed that Brand awareness has a positive correlation with Brand Desire. Brand awareness is the first component of an attitude, an emotion. Consumers have a certain emotion towards a brand that is first and foremost about being aware of that brand among competing brands. Brand desire consists of two components: preference and preference. A consumer's interest in a brand is expressed through an emotion of interest. And when it comes to choosing between competing, interchangeable brands, consumers tend to choose the brand that causes the most emotion. The authors in [23] have shown that Brand awareness is a factor affecting the trend of choosing a bank, but the awareness aspect is only two points of view "brand is a system. identity "(AMA, 1960) and" brand is symbolic "(in [29]\& In [30]), the level of brand awareness is limited only to recognizing the name, logo, image, music sign. characteristics of the brand, advertising and promotion programs of the bank ...Community programs, big sponsorships that the bank participates in and special, unique and attractive promotions contribute to helping consumers to identify banks among competing banks. 
Hypothesis H5: Service quality (CLDV) and decision to choose a savings bank of individual customers have positive relationships.

The influence of the factor Products and services of the bank are assessed by easily opening a deposit account or a savings account, providing the service quickly and effectively to help customers not lose much. waiting in line for transactions and products and services are diversified and plentiful, meeting the different needs of consumers. In the era of industrialization and modernization, saving time is one of the criteria that customers are aiming for. Individual customers who come to the savings bank do not want to spend a lot of time on paperwork and procedures with a series of cumbersome and complicated processes. Therefore, the element of ease of opening an account and providing services quickly and efficiently can affect the choice of a bank.

Besides, as mentioned above, the service needs of individual customers are often diverse. A customer can both have a need for both short-term savings and long-term savings. In addition, customers come to certain banks first to save money, but later can use many other services such as wire transfer, payment for electricity and water bills, receiving remittances, borrowing money $\ldots$ and vice versa. Therefore, diversified and diversified products and services with clear and accurate information are a factor worth considering when using a savings service at a bank.

Hypothesis H6: Related person influence (AHLQ) and decision to choose a savings bank of an individual customer with a positive relationship.

In [31], when people start to want to save money, they collect information about the brand and savings deposit products. of many different banks, thereby making decisions on choosing a bank to save money. Information about brands and product characteristics can be based on their own experiences, or on the recommendations or judgments of others. Therefore, the referral of a third party can be one of the factors influencing the decision-making process of choosing a bank to deposit a customer's savings. The recommendation of family members, friends and the bank staff who are transacting are 3 observed variables used to evaluate the Referral factor. Friends and relatives who have been using the bank's savings deposit service are a useful basis for new customers to choose which bank to save, based on practical experience, understanding and feeling.

In addition, the bank's employees who are transacting are also a valuable source of reference for customers. Usually, individual customers come to the bank not only to use the savings deposit service. They may have made transfers, withdraw money remittances, pay for goods ... before and have a rough feeling about the bank is transacting. At that time, the bank's staff was the bridge leading customers to their bank's savings service.

Hypothesis H7: The form of marketing promotion (HTCT) and the decision to choose a savings bank of individual customers have a positive relationship.

The role of marketing activities in the banking business is not much different from other business areas in conveying information from banks to customers and vice versa. In [24], the author has shown that attitude towards marketing has an influence on the brand desires of consumers. If they have a good attitude and are interested in the branding of a product or brand; distinguish it from competing products and brands; and when there is a demand, the ability to choose for that product or brand is very high.

Thus, the above factors have been tested in many previous studies. However, since most studies have been done in foreign countries, in many different territories, at different times, with separate observers, the results need to be checked for conformity. such as adjustments and supplements through pre-use research to determine the factors that actually affect the choice of banks to deposit money of individual customers.

Table 1: Summary of factors in the proposed research model

\begin{tabular}{|l|c|c|l|}
\hline \multicolumn{1}{|c|}{ Factor } & Encode & Hypothesis & \multicolumn{1}{|c|}{$\begin{array}{c}\text { Related } \\
\text { studies }\end{array}$} \\
\hline Financial benefits & LITC & + & {$[21] ;[16]$} \\
\hline The safety & AT & + & {$[31] ;[14]$} \\
\hline Convenience & TT & + & $\begin{array}{l}{[20] ;[16] ;[14} \\
] ;[32]\end{array}$ \\
\hline Brand person & AHLQ & + & {$[16] ;[32]$} \\
\hline Service quality & TH & + & {$[23] ;[14]$} \\
\hline $\begin{array}{l}\text { Related } \\
\text { influence }\end{array}$ & HTCT & + & {$[14]$} \\
\hline $\begin{array}{l}\text { The form of } \\
\text { marketing promotion }\end{array}$ & QD & & $\begin{array}{l}{[16] ;} \\
{[32]}\end{array}$ \\
\hline Selection decision & & \\
\hline
\end{tabular}

(Source: Author compiled, 2020)

\subsection{Research model}

The multivariate linear regression equation of this study has the form:

Overall regression function:

$\mathrm{QD}=\beta 0+\beta 1 \mathrm{LI}+\beta 2 \mathrm{AT}+\beta 3 \mathrm{TT}+\beta 4 \mathrm{TH}+\beta 5 \mathrm{CLDV}+$ $\beta 6$ AHLQ $+\beta 7 \mathrm{HTCT}+\mathrm{ei}$

Inside:

- QD: Decided to choose individual customer's savings bank

- Financial benefits (LI)

- $\quad$ Safety (AT)

- $\quad$ Convenience (TT)

- $\quad$ Brand (TH)

- Quality of service (QoS)

- Affected person effects (AHLQ)

- Marketing form (HTCT)

The regression model will find out the independent factors that affect the dependent factor. At the same time, the model also describes the impact level, thereby helping us predict the value of the dependent factor. 


\section{Result}

On the basis of influencing factors that were discovered in the research phase, the survey questionnaire was deployed to the identified survey subjects in the form of direct to individual customers. After giving out 400 surveys to individual customers in the form of live broadcast. Results of 305 votes were collected, processed again, of which 285 votes were met. Data used in the research of the topic are data obtained directly from the survey tables that have been cleaned to eliminate incomplete or inadequate survey responses to the research requirements.

\subsection{Age}

The results show that out of a total of 285 survey samples meeting the requirements, there are some couples $18-25$ years old accounting for $5.3 \%, 25-40$ years old accounting for $39.3 \%$, the age from 40-60 accounts for $37.2 \%$ and Finally, the age over 60 accounts for $18.2 \%$. The analysis results show that people aged 25 60 are often more interested in choosing a bank to save money, this is also a group of people with the ability to generate income and want to preserve their numbers. your money is safe and look for income from your savings.

\subsection{Education level}

Surveying 285 customers on factors affecting the decision to choose savings banks at commercial banks in Da Nang city, 1.1\% of customers have high school education, $61.4 \%$ and $36.5 \%$ of clients have college / university degrees, $1.1 \%$ of customers have graduate degrees.

\subsection{Income}

Surveying 285 customers about factors affecting the choice of savings banks of individual customers at commercial banks in Da Nang city, customer groups with income from 5-10, customer groups goods with income from 10-50 million accounts and group of over 50 million accounts for the main proportion, this is also potential customers of the bank in mobilizing savings deposits.

\subsection{Type of agency}

Thus, there are $53 \%$ of customers working in state agencies, $18.9 \%$ of customers working in joint stock companies, $28.1 \%$ of customers working in joint ventures and the rest working in joint ventures. private companies and self-employed. Thus, the group of customers working at state agencies or joint ventures is the group most likely to deposit savings at banks.

After removing the unreliable observed variables, including: $\mathrm{TH} 4$, CLDV4, AHLQ2, CT1, CT2, CT3 according to the evaluation results above, re-test the Reliability of the scale with variables. The remaining results show as follows:

Table 2: Results of reliability analysis and factor analysis

\begin{tabular}{|c|l|l|c|c|}
\hline No & \multicolumn{1}{|c|}{$\begin{array}{c}\text { Group } \\
\text { variables }\end{array}$} & $\begin{array}{c}\text { Number of } \\
\text { observation } \\
\text { variables }\end{array}$ & $\begin{array}{c}\text { Cronbach's } \\
\text { Alpha }\end{array}$ \\
\hline 1 & $\begin{array}{l}\text { Financial } \\
\text { benefits }\end{array}$ & LITC & 3 & 0.823 \\
\hline
\end{tabular}

\begin{tabular}{|l|l|l|c|c|}
\hline 2 & The safety & AT & 4 & 0.835 \\
\hline 3 & Convenience & TT & 4 & 0.782 \\
\hline 4 & Brand & TH & 3 & 0.844 \\
\hline 5 & Service quality & CLDV & 3 & 0.843 \\
\hline 6 & $\begin{array}{l}\text { Selection } \\
\text { decision }\end{array}$ & QD & 3 & 0.939 \\
\hline \multicolumn{4}{|c|}{ (Source: Analysis results from SPSS 16.0 software) }
\end{tabular}

Table 3: KMO coefficients and Bartlett's tests of independent factors

\begin{tabular}{|l|l|l|}
\hline \multicolumn{2}{|l|}{ KMO coefficient } & .800 \\
\hline \multirow{3}{*}{ Bartlett's test } & Approx. Chi-Square & 4250.315 \\
\cline { 2 - 3 } & Df & 171 \\
\cline { 2 - 3 } & Sig. & .000 \\
\hline
\end{tabular}

Rotated Component Matrix ${ }^{\mathrm{a}}$

\begin{tabular}{|c|c|c|c|c|c|}
\hline & \multicolumn{5}{|c|}{ Component } \\
\hline & 1 & 2 & 3 & 4 & 5 \\
\hline CLDV2 & .798 & & & & \\
\hline CLDV1 & .789 & & & & \\
\hline CLDV3 & .787 & & & & \\
\hline TH2 & .646 & & & & \\
\hline TT3 & .623 & & & & \\
\hline TH1 & .578 & & & & \\
\hline TH3 & & & & & \\
\hline AT2 & & .832 & & & \\
\hline AT3 & & .791 & & & \\
\hline AT4 & & 679 & & & \\
\hline AT1 & & .649 & & & \\
\hline TT1 & & .593 & & & \\
\hline AH3 & & & .827 & & \\
\hline AH1 & & & .788 & & \\
\hline LITC1 & & & & .772 & \\
\hline LITC3 & & & & .771 & \\
\hline LITC2 & & & & .734 & \\
\hline TT2 & & & & & .841 \\
\hline TT4 & & & & & .638 \\
\hline
\end{tabular}

(Source: Analysis results from SPSS 16.0 software) 
The multivariate linear regression equation of this study has the form:

Overall regression function:

$\mathrm{QD}=\beta 0+\beta 1 \mathrm{~F} 1+\beta 2 \mathrm{~F} 2+\beta 3 \mathrm{~F} 3+\beta 4 \mathrm{~F} 4+\beta 5 \mathrm{~F} 5+\beta 6 \mathrm{~F} 6+\mathrm{Ui}$

Sample regression function:

$\mathrm{QD}=\beta^{\wedge} 0+\beta^{\wedge} 1 \mathrm{~F} 1+\beta^{\wedge} 2 \mathrm{~F} 2+\beta^{\wedge} 3 \mathrm{~F} 3+\beta^{\wedge} 4 \mathrm{~F} 4+\beta^{\wedge} 5 \mathrm{~F} 5+\beta^{\wedge}$ $6 \mathrm{~F} 6+\mathrm{ei}$

Inside: bank

QD: - Decided to choose the individual customer's savings

- F1 Service quality, includes variables CLDV2, CLDV1, CLDV3, TH2, TT3, TH1.

- F2 Safety, includes variables AT2, AT3, AT4, AT1, TT1.

- F3 Related effects, includes variables AH3, AH1.

- F4 Financial benefit, includes variables LITC1, LITC3, LITC2.

- F5 Convenience, includes variables TT2, TT4.

The regression model will find the independent factors that affect the dependent factor. At the same time, the model also describes the impact level, thereby helping us predict the value of the dependent factor.

The regression results in SPSS are as follows:

Table 4: Regression coefficients

\begin{tabular}{|c|c|c|c|c|c|}
\hline \multirow{2}{*}{ Factor } & \multicolumn{2}{|c|}{$\begin{array}{c}\text { Unstandardized } \\
\text { Coefficients }\end{array}$} & $\begin{array}{c}\text { Standardized } \\
\text { Coefficients }\end{array}$ & T value & Sig. \\
\cline { 2 - 5 } & B & $\begin{array}{c}\text { Standard } \\
\text { error }\end{array}$ & Beta & & \\
\hline Constant & -1.905 & .040 & & .000 & 1.000 \\
\hline F1 Service quality & .632 & .040 & .632 & 15.942 & .000 \\
\hline F2 Safety & .314 & .040 & .314 & 7.915 & .000 \\
\hline F3 Related effects & .218 & .040 & .218 & 5.509 & .000 \\
\hline F4 Financial benefit & .092 & .040 & .092 & 2.324 & .021 \\
\hline F5 Convenience & .085 & .040 & .085 & 2.146 & .033 \\
\hline
\end{tabular}

(Source: Analysis results from SPSS 16.0 software)

The regression results show that 5 independent factors from $\mathrm{F} 1$, F2, F3, F4, F5 are statistically significant, sig $<0.05$ is satisfactory, so they will be retained in the research model.

Table 5: Model Summary

\begin{tabular}{|r|c|c|c|c|}
\hline Model & $\mathrm{R}$ & $\begin{array}{c}\mathrm{R} \\
\text { Square }\end{array}$ & $\begin{array}{c}\text { Adjusted } \\
\text { R Square }\end{array}$ & $\begin{array}{c}\text { Std. Error of } \\
\text { the Estimate }\end{array}$ \\
\hline 1 & $.749^{\mathrm{a}}$ & .561 & .554 & .66814717 \\
\hline
\end{tabular}

(Source: Analysis results from SPSS 16.0 software)
Based on the results in the table above, ANOVA has value Sig $=0.000<0.05$, so the hypothesis $\mathrm{H} 0$ is rejected, assuming the hypothesis H1. That means the model exists.

In other words, with 5\% significance, it can be concluded that the decision to choose a savings bank of an individual customer is influenced by at least 1 of the remaining 5 factors:

The regression results showed that the Durbin-Watson Statistics was 2,182 . Thus, the model exists and with $d=2,219 \square$ 2,0 , we can conclude that the model does not exist negative or positive autocorrelation.

So, the regression estimation model would be:

$\mathrm{QD}=-1.905+0.632 \mathrm{~F} 1+0.314 \mathrm{~F} 2+0.218 \mathrm{~F} 3+0.092 \mathrm{~F} 4+$ $0.085 \mathrm{~F} 5$

The standardized regression would be:

$\mathrm{QD} *=0.632 \mathrm{~F} 1 *+0.314 \mathrm{~F} 2 *+0.218 \mathrm{~F} 3 *+0.092 \mathrm{~F} 4 *+$ $0.08 \mathrm{~F} 5 *$

And the model of quantitative research results takes the form:

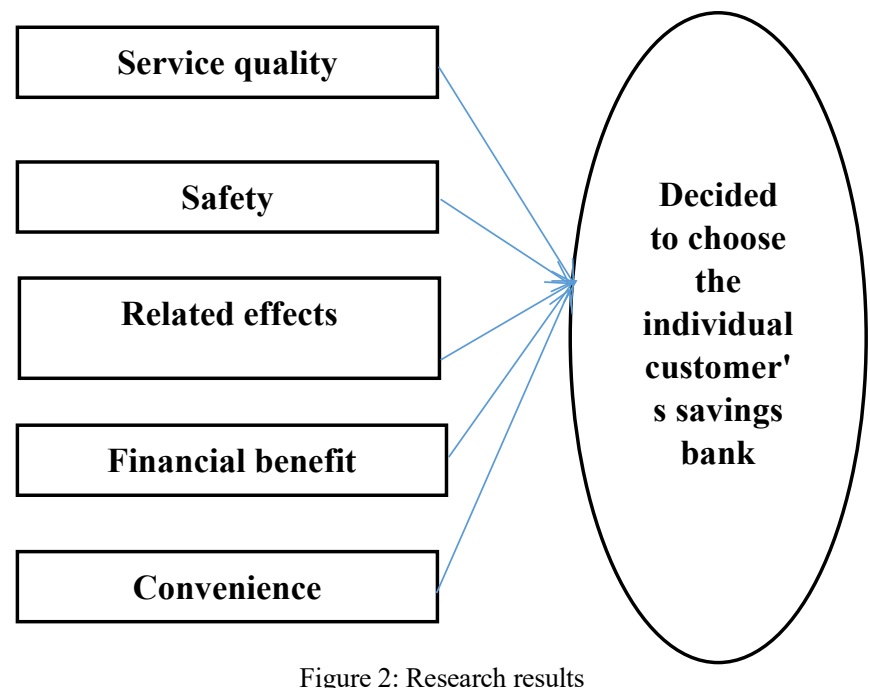

Linear regression model using Enter method is made with a number of assumptions and the model only really makes sense when these assumptions are guaranteed. Therefore, to ensure the reliability of the model, the topic must also evaluate the violation of necessary assumptions in linear regression. From the result in Figure 4.5 , we have $1<\mathrm{d}=2.219<3$ so we can conclude that the remainder are independent of each other and that the independence of the remainder is guaranteed. [33]

Finally, we will consider the multi-collinearity violation of the model. In the above correlation coefficient analysis, we have seen that the dependent variable has a fairly clear correlation with the independent variables, but we can also see that there is correlation between the independent variables. This will create the model's multicollinearity capability. Therefore, we have to detect multicollinearity phenomenon by calculating the acceptability of the variable (Tolerance) and the variance inflation factor (VIF).

Thus, the linear regression model built according to the above equation does not violate the necessary assumptions in linear regression. 


\section{Conclusion}

With the survey results including the number of samples of 285 for a regression model including 7 groups of factors affecting the decision of individual customers to choose a savings bank at commercial banks in Da Nang city. . The quantitative research results show that there are 5 groups of factors that greatly affect the decisions of individual customers to choose a savings bank: Service quality, Safety, Related effects, Benefits financial benefits, convenience

\subsection{Improving the quality of banking services}

Besides expanding the banking network, increasing investment in facilities and techniques, developing many convenient products to attract customers; Banks are constantly making efforts to perfect products, improve the quality of care and serve customers. Products and services are factors affecting customers' choice of banks to save savings. Because customers come to the bank, apart from the purpose of saving, have many other needs such as transferring money, paying bills ... Providing enough services according to customers' needs is also one of the attractive measures. Personal savings deposit. Therefore, the improvement of aspects related to the retail products and services that the bank offers to customers, including product variety, simplification of procedures, and time savings. , and there are different preferential policies depending on different subjects.

\subsection{Increase safety for customers when sending money}

With specific regulations on insured deposits, rights and obligations of the sender, payment limit, time of interest payment ... has shown the Bank's commitment and the State to ensure security. safety of depositors' deposits aims to best protect the legitimate rights and interests of depositors, ensure the safety and health of banking operations and handle financial crisis. In addition, the Bank needs to build support channels to help customers easily use smart services, tools and utilities to check their savings accounts at the Bank anytime, anywhere like channel. at the counter (account balance confirmation service), Internet Banking channel (for customers registered to use iPay service) or automatic answering switchboard channel (TPIN) ... As recommended by the Bank, customers Customers must also protect themselves when depositing money through the implementation of bank recommendations. Customers register SMS Banking with the Bank, enter the correct customer number or ID card to automatically look up the following information: Account balance, account number, last 5 transactions of the account account accounts, savings book balance, card status, exchange rate, savings interest rate, information on products, services, promotions....

\subsection{Improve financial benefits for depositors}

The research results show that among the factors individual customers will consider when choosing a bank to save money, financial benefits are the most important factor. In which, the observed variable "financial benefits" received a high consensus. It can be said that savings depositors appreciate the bank's financial capacity. Therefore, improving financial benefits is one of the conditions for banks to attract customers.
Financial benefits are shown through three aspects, including interest rates on savings deposits, fees applied to products and services and regular promotions. In general, this is one of the top concerns when customers use the bank's products and services. However, in Vietnam, issues related to interest rates are strictly managed by the State Bank of Vietnam through the ceiling deposit rate applicable to commercial banks. As more and more customers need convenience, the online savings channel becomes preeminent, especially for the group of 'digital customers'. Therefore, banks should encourage customers to deposit online savings with bonus interest rates, which is seen as a positive move proactively following customer needs and is a competitive factor in the market when The convenience of digital banking is becoming more and more popular in Vietnam. Both the Bank and the customers save translation time, and have established themselves in the retail industry with recognition from international organizations.

\subsection{Increased convenience for customers to send money}

Bank savings is always the first choice for unused idle money. However, many customers, when saving money, do not deposit all their idle money because they are afraid that they cannot withdraw their money when they need money, or they must withdraw their interest before their due date. Therefore, the bank needs to offer a solution for customers that should split the savings book instead of just depositing all the money in one book. Along with that, the bank needs to expand its network through increasing the number of transaction points, the banks also invest heavily in renovating the transaction space of the existing branches, providing a spacious transaction space. page, spacious, creating maximum comfort for customers. At the same time, banks also promote digital banking and gradually affirmed themselves with recognition from international organizations. On the digital banking platform, customers easily perform hundreds of types of services, from paying bills for electricity, water, telecommunications, monthly insurance to fast money transfers within 5 minutes for bank accounts. other goods

\section{References}

[1] I. Ajzen, "The theory of planned behavior." Organizational behavior and human decision processes, 50(2), 179-211, 1991

[2] P. Luarnand and H.H. Lin, "Toward an understanding of the behavioral intention to use mobile banking." Computers in human behavior, 21(6), 873$891,2005$.

[3] V. Venkatesh, S. M. Walton, and J. Y. L. Thong, "Consumer acceptance and use of information technology: extending the unified theory of acceptance and use of technology." MIS quarterly, 157-178, 2012

[4] C.-S. Yu, "Factors affecting individuals to adopt mobile banking: Empirical evidence from the UTAUT model." Journal of electronic commerce research 13(2), 104, 2012

[5] H. Q. Cuong, Research on factors affecting the intention to use online shopping services (Nghiên cứu các yếu tố ảnh hưởng đến ý định sử dụng dịch vụ mua hàng điện tử qua mạng), National University of Ho Chi Minh City, 2020

[6] L. T. T Hang, Research on bank savings behavior of individual customers in 2012 (Nghiên cứu hành vi gửi tiền tiết kiệm ngân hàng của khách hàng cá nhân năm 2012). Doctoral thesis, Academy of Social Sciences, 2012

[7] B. K. Jeong, M. Khouja, and K. Zhao, "The impacts of piracy and supply chain contracts on digital music channel performance." Decision Support Systems 52(3), 590-603, 2012.

[8] M. Fishbein and I. Ajzen, "Belief, attitude, intention, and behavior: An introduction to theory and research.", 1977.

[9] I. Ajzen, "From intentions to actions: A theory of planned behavior." Action control. Springer, Berlin, Heidelberg, 11-39, 1985 
[10] W. T. Anderson, E. P. Cox and D. G. Fulcher, "Bank Selection Decisions and Market Segmentation: Determinant attribute analysis reveals convenienceand sevice-oriented bank customers." Journal of Marketing, 40(1): 40-4, 1976. DOI: $10.1177 / 002224297604000107$

[11] D. D Schram, C. C. Darling Milloy, and W. E. Rowe, "Juvenile sex offenders: A follow-up study of reoffense behavior". Community Protection Research Project, Washington State Institute for Public Policy, 1991.

[12] K. Khazeh, and W. H. Decker, "How customers choose banks." Journal of Retail banking 14(4), 41-45, 1992.

[13] D. H. Tootelian and R. M. Gaedeke, "Targeting the college market for banking services." Journal of Professional Services Marketing 14(2), 161$172,1996$.

[14] E. Mylonakis, E. L. Hohmann, and S. B. Calderwood, "Central nervous system infection with Listeria monocytogenes. 33 years' experience at a general hospital and review of 776 episodes from the literature." Medicine 77(5), 313-336, 1998.

[15] S. Mokhlis, N. Hazimah, N. Mat, and H. S. Salleh, "Commercial bank selection: the case of undergraduate students in Malaysia." International Review of Business Research Papers 4(5), 258-270, 2008.

[16] C. Chigamba, and O. Fatoki, "Factors influencing the choice of commercial banks by university students in South Africa." International Journal of Business and Management, 6(6), 66, 2011

[17] H H. Siddique, "Bank selection decision criteria employed by indian expatriates in sultanate of oman: an empirical analysis." International Journal of Business and Management Studies 4(2), 55-64, 2012.

[18] S. S. Almejyesh and K. S. Rajha, "Behavioral determinants and their impact on customer savings deposits in Islamic banks in Saudi Arabia." Journal of Islamic Banking and Finance 2(1), 163-186, 2014

[19] C. I. Enyinda, "Evaluation of relationship marketing in Islamic banks in the UAE: Empirical evidence based on sensitivity analysis algorithm." Journal of Economic \& Financial Studies 2(3), 01-12, 2014.

[20] A. Sajeevan Rao, and R. K. Sharma, "Bank selection criteria employed by MBA students in Delhi: An empirical analysis." Journal of business studies Quarterly 1(2), 56-69, 2010.

[21] S. Mokhlis, H. S. Salleh, and N. H. N. Mat, "What do young intellectuals look for in a bank? An empirical analysis of attribute importance in retail bank selection." Journal of Management Research 3(2), 1-15, 2011.

[22] R. I. Sabir, Ghafoor, O., Akhtar, N., Hafeez, I., and Rehman, A. U, "Factors affecting customer satisfaction in banking sector of Pakistan." International review of management and business research 3(2), 1014, 2014

[23] P. T. Tam, and P. N. Thuy, Factors affecting individual customers' tendency to choose the Bank (Yếu tố ảnh hưởng đến xu hướng lựa chọn Ngân hàng của khách hàng cá nhân). Journal of Banking Science and Training, 103, April 2010.

[24] N. T. Gam, Research on factors affecting individual customer satisfaction for Joint Stock Commercial Bank for Industry and Trade East Hanoi Branch, (Nghiên cứu các yếu tố ảnh hưởng đến sự thỏa mãn của khách hàng cá nhân đối với ngân hàng thương mại cổ phần Công thương Chi nhánh Đông Hà Nội). Science \& Technology Magazine, 81, 33-40, 2011.

[25] L. M. Linh, Research on customer satisfaction and loyalty to banking services in Hau Giang province (Nghiên cứu sự hài lòng và trung thành của khách hàng đối với dịch vụ ngân hàng trên địa bàn tỉnh Hậu Giang), Journal of Social Sciences and Humanities, 12, $34-41,2014$.

[26] P. D. Khoi, Factors affecting customer satisfaction with savings deposit services: The case of Agribank Binh Minh, Vinh Long (Các nhân tố ảnh hưởng đến mức độ hài lòng của khách hàng đối với dịch vụ tiền gửi tiết kiệm: Trường hợp Agribank Bình Minh,Vĩnh Long). Scientific Journal of Can Tho University, 40, 50-57, 2015. Doi: 10.1263/03697854100265

[27] N. N. D. Phuong, Factors influencing individual customers' decisions to save money - Research at Joint Stock Commercial Bank for Industry and Trade of Vietnam (Các nhân tố ảnh hưởng đến quyết định gửi tiền tiết kiệm của khách hàng cá nhân - Nghiên cứu tại Ngân hàng Thương mại cổ phần Công Thương Việt Nam). Industry and Trade Magazine, No. 01, June 2014

[28] N. D. Tho, and N. T. M. Trang, Research the components of brand equity and measure them in the consumer goods market in Vietnam (Nghiên cứu các thành phần của giá trị thương hiệu và đo lường chúng trong thị trường hàng tiêu dùng tại Việt Nam). Ministry-MSB-level scientific research project, 2233,2002

[29] J. N. Kapferer, Die Marke, Kapital des Unternehmens. No. hal-00788645. 1992.

[30] D. A. Aaker, "Measuring brand equity across products and markets." California management review 38.31996.

[31] P. Gerrard and J. B. Cunningham, "Singapore's undergraduates: how they choose which bank to patronise." International Journal of Bank Marketing, 2001. Doi: $10.1108 / 02652320110388531$
[32] J. Tank and K. Tyler, "UK student banking revisited: influences and the decision-making process." Journal of financial services marketing 10(2), 152164, 2005. Doi: $10.1177 / 002224297604068954$

[33] H. Trong and C. N. M Ngoc, Research Data Analysis with SPSS (Phân tích dữ liệu nghiên cứu với SPSS (Tập 1)), Statistical Publishing House, Ho Chi Minh City, 2008 